\title{
The Miasma of Contradictions and Malicious Relationships in Strindberg's Plays: A Biographical Approach
}

\author{
Noorbakhsh Hooti
}

\begin{abstract}
In the recent years, researchers in anthropology, political science, psychology, and sociology have begun to study how group identifications contribute to conflict, how intergroup conflict can influence identity, and, most recently, how identities might be harnessed to reduce intergroup hostility. Strindberg was able to objectify his inner conflicts, and to some extent his characters reflect the universal predicaments of mankind. Thus, though Strindberg's philosophy stems from and expresses his psychological tensions, its ultimate significance lies in its universal appeal. The attempt of this paper is to focus, not on Strindberg's psychology only but also explore the dimensions of his philosophy as it becomes manifested in his work. The study tries to reach its goal by having a journey in Strindberg's personal life. The attempt to explore the causes, consequences and nature of the contradictions, conflicts and the malicious personal relationships in Strindberg's plays, the study will be focusing on the following plays, The Father (1887), Miss Julie ( 1888), Creditors ( 1890), The Link (1897) A Dream Play (1902) and The Ghost Sonata (1907). As The Road to Damascus (1898) is central to Strindberg's philosophy, on this theme, the study also intends to give a brief look at this trilogy.
\end{abstract}

Keywords: Strindberg, miasma, contradictions, trilogy.

\section{Introduction}

Reading through Strindberg's plays one finds the recurrent theme of man-woman relationship since this is the primary relationship from which originate all other relationships. Strindberg's exploration of the tensions inherent in it, becomes his way of understanding the problems of the world. For Strindberg the world is divided between the Male and the Female principles. In A Dream Play (1901), he gives expression to his very unchristian conception of the world as being the product of a union between the Male and the Female principles, that of "Brahma, the divine primal force" and "Maya, the world mother" (Meyer, 1964: 250) as this union also represents for Strindberg the impossible coming together of two opposite forces, that of the spirit and the flesh, the world in consequence becomes the home of irreconcilable dualities, dualities which create the condition of perpetual strife in human lives. Thus, man, composed of these warring elements becomes a divided being, and this tension between his conflicting selves gets most evidently manifested in the battle of the sexes. Strindberg further uses the emblem of sexual conflict to represent social strife in his plays. The domestic sphere is a microcosm of the world and that which infects the most basic unit of society, ultimately affects the whole society-the domestic thus, translates into the universal. 
Strindberg's life to a large extent explains his works and his philosophy. Taking a biographical approach, critics view Strindberg's fascination with the battle of the sexes as originating in his unhappy relationships with the women in his life and his divided sensibilities. Brustein (1965: 320-21) points to:

how Strindberg the son of a servant and a déclassé aristocrat, regarded the circumstances of his birth as the source of all his later troubles- For instance he felt that, as a result of this union, his sympathies were continually divided between the peasant and the aristocrat- and his demeanor kept vacillating between peasant servility and aristocratic arrogance.

His father had married his mother when she was pregnant with their fourth child, that is, Strindberg. Conceived out of wedlock and born prematurely, he felt he was unwanted and illegitimate. He described himself as a pariah-outlawed from paradise, a beggar, homeless among his own people. He lived a life of voluntary exile and imagined himself as a rebel-a kind of Faust figure. On the other hand he also felt that he was born without a 'Will' because he was born against his parent's will. This was essentially a passive and feminine self-image that was at odds with the rebel, masculine image. The dualism of his psyche gets reflected in his ambivalent feelings towards his mother and women in general. He adored his mother, and as he had to fiercely compete with his other eleven siblings for her attention he felt abandoned and re ejected by his mother and hated her for preferring his other brothers to him. His Oedipal adoration of the mother made him harbour ambivalent feelings of hate, fear, and respect towards his father.

Strindberg was deeply attracted towards the figure of the chaste Madonna, a kind of older motherly woman who was sexless, kind and compassionate. Shortly before his death, in response to a questionnaire regarding which characteristic he prized most highly in a woman, he had replied 'Motherliness'. Cooper (1992) comments that like most men it was the Mary figure, the mother of Christ, he loved in women and loathed the Eve figure in them. Eve who would not blindly submit to authority. In addition she was modern, emancipated, masculine, unfaithful, competitive, and un-maternal. Things get complicated when these two distinct categories of women merge to form the image of the Spiderwoman, a mother figure who is sexually desirable and who is obsessed with female domination. She is a kind of vampire that sucks away a male's virility and emasculates him. The wife as both mother, and the mistress taints the relationship with the stain of incest. Laura in The Father represents such a type; she is a nurse, mother, wife and mistress all rolled into one. Laura cleverly manipulates these roles to effectively emasculate the Captain and reduce him to the level of a helpless child by the end of the play.

Strindberg was both attracted and repelled by women. He married beautiful, talented women whom he believed also had a maternal side. He sought in his women an emblem of sensuous maternity - a combination of the Madonna and Eve, the chaste mother and the erotic belle. His first wife, Siri von Essen, epitomized the ideal woman, fair haired and blue eyed with the face of a child. When Strindberg met her she was already a wife and a mother. He was captivated by her Madonna image and convinced himself that his love for her was purely spiritual. He married her in 1877, after her divorce from Baron Wrangle, a Guard Officer. His marriage to Siri, a moderately successful actress had its share of happy and turbulent moments. The marriage lasted nearly fourteen years and ended owing to Strindberg's growing jealousy and paranoia. On his deathbed he confessed that Siri was the only woman he had truly loved. His other two marriages to authoress Frida Uhl in 1893 and actress Harriet Bosse in 1901 too failed. Valency (1963: 244) believed that: 
Strindberg felt threatened by their success; he also suffered from persecution complex and feared that the feminists were plotting to kill him. The castrating, emasculating, vampirish women of his plays probably have their origins in this fear.

Thus, his neurosis partly contributes to his ambivalent representation of the manwoman relationship.

\section{Argument}

Strindberg is more modern, more realistic, when displaying people who are victims of their passions and at the same time vulnerable and helpless, sometimes shattered by the collective forces they have to contend with.

Hummel's statement in The Ghost Sonata ( 1907) that his "entire life's been like a book of stories ... all different ... [but] Strung together on a sort of recurring theme" (Allen, 1960:103) illustrates the nature of Strindberg's plays, all of' which are linked through the theme of malicious and stultifying relationships. In this chain, Strindberg's play The Link (1897) marks the end of his naturalistic phase and the beginning of his expressionistic phase. (Harris, 1979).

Naturalism as a philosophical doctrine denies the existence of metaphysical or supernatural phenomena and concentrates solely on the material world. The strictly naturalistic view was mechanistic, psychological, and deterministic. Man is seen as puppet and victim of these inexorable forces. Most naturalists demonstrated a concern with the animal or irrational motivations of human behavior, sometimes manifested in connection with sexuality and violence. Individuals were seen as simply the product of heredity and a particular environment, motivated by inner instinctual drives and pressured by the forces of society without. They had little will or responsibility for what took place in their lives. Thoughts, desires, intentions, feelings and actions all arise on their own without the benefit of a supervisory self, and they are all products of a physical system, the brain and the body.

Expressionist dramatists tried to convey the dehumanizing effects of $20^{\text {th }}$ century technological society through such devices as minimal scenery, sudden shifts from prose to verse from objective reality to highly subjective monologue, from conventional dialogue to telegraphic utterance, and characters portrayed as types rather than as individuals. Unnecessary details were eliminated and the characters were often representatives of states of mind or social positions. They used the grotesque to distort reality and present a totally personal viewpoint. The emphasis in many cases was not on visual details but on visionary experiences in an effort to objectify complex psychological states and gain mystical access to permanent values. The style was a conjunction of extremes-compression with expansiveness, clipped logicality with hymnic incantation, the concrete with abstraction, the sublime with the prosaic. The settings were often abstract, shadowy and colourless.

The Naturalistic phase spans the years 1886-1889. The Inferno years intervening, To Damascus (1898) marks the beginning of the new phase. Coming midway between the two phases, it contains the essence of what he has already dealt with, in detail, and also suggests many of the ideas he was to develop in his Dream Plays. Thus, it would be convenient, for 
this once, to discard chronology and begin the discussion on the problem of malicious relationships with an analysis of this play of his middle period.

The Link presents in a compact form, the nature of the conflict between the sexes. It begins with a consideration of the legal outcome of this conflict (i.e. divorce) and then uses it, to further reflect on the human problems behind it. The Sheriff in the opening scene presents legalistically the complexity of the problem, "in this case [i.e. the man-woman relationship] it is not easy to tell who is guilty, for both parties are at once complainants and defendants" (1979:20). In other words each in himself is both the victim and the victimizer; victims of their own prejudices, they victimize themselves and others, by entering into false relationships. It mostly happens when we (here, we referes to man in general) suffer the duality of self and do not see what we are just see what we are not. We see others with more optimism and ourselves with pessimism. As Wheeler (2006:5)says " believing that others have something we do not, this not really true, but the concept generates mental doubt and additional suffering"

The protagonists of The Link, the Baron and the Baroness, are shown as isolated individuals; victims of their prejudices, they cannot come together at any point. At the onset of the play we see them idealistically agreeing to refrain from mutual recriminations, but as soon as the proceedings begin they immediately start to accuse each other. That they could ever have come together to create a relationship seems surprising. But one has only to take a close look at their habit of deliberately masking their selfish drives, through idealisms, to explain their coming together. We see that though the illusion of conformity created by their idealisms allowed them to come together, the resultant relationship is basically a false one and hence prone to disruptive forces from within and without. Thus, at the slightest instigation the masks are thrown off and the latent violence and aggression gets unleashed. For example, in the course of the play, the Baron's selfishness is slowly exposed. We see that, though the Baron had, sworn to have destroyed the documents establishing his wife's adultery, for the idealistic reason of love, he in fact had preserved them in order to take revenge, which he does by frustrating his wife's claim to the child and proving his power over her. The falseness of the relationship further gives rise to ambivalences within it. When these ambivalences get further aligned to the basic opposition between the sexes they give rise to abnormal tendencies in love relationships. The Baron for instance suggests that "the Baroness' love is masochistic, because she loved him most when he was unfaithful to her. (1979: 37)." Calling her abnormal could be the Baron's way of taking revenge and justifying his infidelity. The Baroness on the other hand takes her revenge, by insidiously negating the Baron's maleness by bringing up his son as the Baron unconsciously alerts us to the fact when he states:

Our son has your body, but my soul, and that soul you cannot rid him of. In him you will have me back when you least expect it; in him you will find my thoughts my tastes my passions, and for this reason you will hate him one day as you hate me now. That is what I fear! (42).

The Baron's fear of her hatred is legitimate because we realize that by thwarting her son's growth into manhood, the Baroness is symbolically castrating her husband and effectively taking away from him his hope of immortality through the child. In her at-tempts to undercut the male identity by feminizing it, she resembles a type of Omphale, who recurrently appears in Strindberg's plays and is viewed as a vampire. 
In these relations between the sexes, love and hate coexist, and the resultant conflict creates the destructive spectacle of the slaughter house. Hatred in fact "is the lining of the coat of love" (33). The play also suggests that there is no escape from this conflict and the situation of mutual lies and faithlessness it creates. Though the Baron and the Baroness contemplate both the options of separation or starting all over again, they are all the time acutely aware of' the impossibility of doing so. Though they "have gone too I'M- and "are enemies of life" (37) they cannot separate; the child ties them and in fact becomes the emblem of their imprisonment-in whom they "must ever meet without wishing to do so" (38). They are curiously tied to each other, like the two sides of a personality. This is most clearly illustrated through the Baron's experience, "I have struck you down, and 1 am bleeding to death myself, for your blood is mine" (41). It also suggests that the impulse to destroy the 'other' inevitably becomes self-destructive. And as such, the destruction of a relationship results in the destruction of both the partners.'

The Link also suggests that the characters are not solely to be blamed for their contradictions. Born with a sex, or into a class from which they cannot escape, they continually aspire towards the opposite. For example, the sorrow of the Baroness' life, like many other women in Strindberg's canon, is that she "was not born a man (43) and therein lies her hatred of men and her desire to undermine them. Heredity too plays its part in creating these riven characters driven by "evil tendencies, hatred and wild passions" from which there is no respite (47). It represents a force beyond their control and introduces an element of fatality into the relationships.

This play's explanation of the universal nature of the conflicts anticipates the philosophy of the dream plays. As everything on this earth is imperfect and human nature is full of falsehood and dissimulation, a state of continual strife and pain becomes the essence of human life.

The Father (1887) portrays the tragedy of Man tainted with inherent antagonisms and dualities (Harris, 1979). This is because:

Men and women seek to destroy each other in the act of loving and creating new life and the new life is itself always guilty . . . by the relationships, it is inevitably born into. For it is used as weapon and prize in the parent's continuing struggle, and is itself unwanted ... [and thus is] haunted by the desires of an impossible return (Williams, 1966: 8).

And the cycle goes on, perpetuating itself through each generation. The Captain in The Father is the product of such a union. Insecure and suffering from the sense of an incomplete self, his tragedy lies in his attempts to complete himself through a woman and the fatal ambivalences it generates. As he himself states, "my father and mother did not want me and consequently I was born without a will. I naturally thought that 1 was completing myself when you and I become one, and therefore you got the upper hand" (Meyer, 1985: 84-8). But Laura's earlier statement that she first entered his life as his "second mother" (1979:83) reflects the ambivalence of his feelings and his actions. By seeking in his wife both a sexual partner and a mother surrogate, he inevitably saddled her with his ambivalences and dualities, thus creating a situation which is best expressed through Laura's words:

Yes, so it was, and therefore I loved you as my child. But you know, you must have seen when the nature of your feelings changed and you appeared as my 
lover I blushed and the .joy of your embraces turned to remorse as if my Wood were ashamed. The mother became the mistress. Ugh! (II.v: 84)

Yet, in it she also suggests her own ambivalences that as a woman, she "could love a man truly only as a mother and thus the sexual relationship involves for her the shame of incest." (Valency, 1963: 270) Inherent in her dualities is the suggestion that they have been created not only by the Captain's conflicting demands on her, but also by forces that are beyond her control.

This fact becomes clear in Laura's explanation of the Captain's mistake:

There was your mistake. the mother was your friend, you see, but the woman was your enemy, and love between the sexes is strife. Do not believe either that 1 gave myself; I did not give, but 1 took what I wanted. You had one advantage, however, that 1 realized and wanted you to realize. (1979: 84)

In connection with this statement, if one recalls Laura's earlier questioning of the Law's declaration that the father has the right to decide the future of his children, one gets a clue to the driving force behind her ambivalent antagonisms. The law is seen by her as a rational and patriarchal construct that overlooks the law of nature, according to which paternity cannot be conclusively proved, whereas maternity can be. "Aligning herself with the laws of nature she asserts the right of matriarchy, which was overthrown to be replaced by patriarchy. (Lamm, 1952:138) Herein lies the root of all sexual conflict. Because the women in their continual efforts to regain their lost power subvert and insidiously undercut all male constructs, they appear as destructive vampires who undermine men (here, the ever lasting conflict between males and females is pointed out). The possibility of a compromise does not exist because one system was completely overthrown to be replaced by the other and thus "one of them must go under in this struggle." (1979: 85)

As patriarchy denies woman the decision-making powers, she takes her revenge on it by power on the level of personal relationships. As the woman commands the higher power in her capacity as mother and nurse, she tends in her relationships with men to view and relate to them on those terms. Her doing so preserves her power and authority, but inevitably gives rise to incestuous suggestions in man-woman relationships. Thus Laura's assertion that the mother was his .friend is highly ambivalent. Because in the end, it is again a mother surrogate, the nurse, Margaret, who successfully thwarts the Captain's manly assertions and reduces him to the level of a whimpering child, finally symbolically castrating him through the straitjacket. Therefore, the study wants to make it a point that these ambivalences behind the sexual conflict taint all human, familial and social ties.

Furthermore, the sexual conflict transforms the basis of love relationships from one of sharing to one of selfish vampirism. Laura does not give but only takes what she wants, and thus reduces the Captain from an equal partner to a dispensable agent. As she says: "Now you have fulfilled your function as an unfortunately necessary father and bread winner. You are not needed any longer and you must go."(86) Laura, is thus an unconscious vehicle of matriarchal assumptions, a type of "Omphale" (99) who unmans Hercules (i.e. the Captain) by under-mining his reason and questioning his virility, by doubting his paternity of Bertha. In this struggle the Captain is defeated by the "treacherous weakness" of women and dies asserting this fact: "A man has no children, it is only women who have children, and therefore the future is theirs, when we die childless" (99). 
Though in this conflict Laura appears as a vampire, she is not solely responsible for the destruction of the Captain and their relationship. The Captain is destroyed, both through his persecution complex which is fostered by his monomania and Laura's cruel persecution of him. In the final analysis, the relationship is destroyed because both Laura and the Captain are victims of paradoxical dualities of manly woman and childish man, respectively. The division ill their personalities creates the conflict and the division in their relationship, which in turn divides the whole household. This process hints at the matter of proliferation of divisive and destructive forces from the personal to the social level. Essentially solitary and preoccupied with their fragmented selves, the characters cannot create harmonious relationships. Separately they may be good but when they come together, they clash and necessarily "torment the life out of 'one another" (65)

Commenting "on the contradictory systems of his daughter's education in The Father the Captain states: "it won't do to try and make a soul in patches like that"(Cooper,1992:54 ). Miss Julie portrays the fate of such a character, possessing a human soul "patched together" out of "torn off samples of Sunday-best clothes that have become rags (1979: xv) Strindberg's explanation of Miss Julie's tragedy illustrates this. "she is a victim of the discord which a mother's 'critic' implanted in a family; a victim of the errors of her age, of circumstances and of her own flawed constitution." ('Preface: xvii)

Miss Julie not only locates the source of malicious personal relationships in the split psyche of its characters but it further develops this theme by convincingly relating the conflict between the sexes to the conflict between the classes. Strindberg establishes this connection in his 'Preface' to the play, in which he states that "he finds the joy of life in life's cruel and mighty conflicts (Allen, 1960: xiii)"; and these for him are the interrelated conflicts between "social ascent and decline, of higher or lower, better or worse, man and woman" (xii). Miss Julie is as much about individual persons as it is about the existing hierarchies and conflict thereof between the genders and social classes. Julie and Jean are individuals in their own right but they also simultaneously represent the affinities and polarities that exist between men and women, the aristocracy and the lower classes. Thus, when Julie the "well favoured individual [goes] under" (xii), it represents the death of her aristocratic family tree and probably the rise of Jean's plebian stock. Strindberg uses the image of the hawk and the flea to further underline the universally predatory motive underlying all these sexual and social relationships or interactions: "The bird of prey eats the dove and the louse cats the bird of prey." (xii) Significantly the categories of dominant and subordinate are not fixed but continually shift and the shifting equations between the predator and prey, oppressor and the victim create the matrix of the play and its action.

The play opens with Julie asserting her right over Jean, her father's servant. Julie snatches Jean away like a predator from Kristin the cook, his fiancée. The opening exchanges between Julie and Jean clearly denote the complex interplay between the sexual and social roles. Julie is attracted toward Jean and is ready to ignore class taboos to dance with him. And yet she is not afraid of rejection because Julie believes that as mistress of the house, she automatically commands Jean's allegiance and that he would unquestioningly obey her orders. Trained to be servile, he would be malleable to be molded as per her fancy. Julie is a type of Strindberg's modern, confused, half-woman who likes to control her men and breaks gender and class hierarchies. Julie has unsuccessfully tried to 'train' her fiancé and hopes to have better luck with the socially inferior Jean. She tutors him to flirt with her and Jean willingly plays along. Julie actively initiates the flirting with Jean. The gender and class imperatives get mixed as she appropriates a traditionally male prerogative on account of her 
class superiority. Being a servant, Jean occupies a feminine position in the class hierarchy but as a male and a natural, sexual aristocrat he attracts Julie and is attracted towards her. He uses his lower class status to his advantage to gain Julie's sympathy and manipulate her. Julie is sexually attracted to Jean because he is not the usual uncouth servant. Jean aspires to be an aristocrat and therefore he apes them and has superficially acquired their refined tastes and mannerisms. Coming from a lower class, he is essentially more 'male' than the effeminate aristocratic men like Julie's fiancé. For instance when Julie orders Jean to flirt with her, he warns her not to play with fire. It is a clear indication that contrary to her belief', her social position does not 'insure' her or warrant sexual superiority or immunity from exploitation. Jean uses her attraction for him to further his ambition to move up socially. Thus, it becomes possible for Julie the aristocratic hawk to be finally brought down by Jean the servile flea.

Jean succeeds because a part of Julie is already inclined to fall. She tells him,

I have a recurring dream from time to time: 1 'm on top of a pillar. I'm sitting there, and 1 see no possible way of getting down. I feel dizzy when I look down but I know I must get down. I haven't got the courage to throw myself. I can't hold on. I long to be able to just fall but 1 don't fall. I know 1 won't have any peace until I'm down, no rest until I'm down, down to the ground. I also know that once 1 am down I'll want the ground to open and for me to sink, sink. (pp. 12-13)

Julie's weak, passive and confused self scripts the downfall of her father, family and lover. Jean on the other hand dreams of moving up; he is a complete contrast to Julie's feminine passivity. He says:

I dream that I am lying underneath a tall tree in a dark forest.... I want to plunder the bird's nest up there with the golden eggs. I climb and climb but the trunk is so thick and slippery and it's so far to the first branch. I know that if I could only reach that first branch I could climb up to the top step by step. 1 haven't reached it yet but I will reach it (13).

He is the opportunist, who will one day be "the founder of a new species ... with the brutality of a slave and the insensitivity of a tyrant" (xviii). Jean's dream of social climbing has a marked sexual undertone. Julie mocks at Jean, telling him that he has a very high opinion of himself. Perhaps, he thinks that he is the legendry lover Don Juan who is irresistible to woman. Or, maybe, he is a personification of the biblical Joseph and women cannot keep away from him.

The complexities and dichotomies of the Jean-Julie relationship become evident right from the onset of the play. Jean is attracted towards Julie both as a woman and as an aristocrat who is beyond his reach. Though he respectfully refers to her as 'Miss Julie,' he is also aware of her as a fine-looking girl with a good pair of shoulders. Thus, at Julie's instigation he for a moment regards her as only a woman and flirts with her. But as Jean cannot for long forget his own class and his ambitions to be upwardly mobile, he soon starts to regard her as a member of the aristocracy who could be used to effect escape from his class. Jean's ambition is most evidently reflected in the veneer of sophisticated manners he has adopted to emulate the aristocracy. As this sophistication does not penetrate into his innermost being, at the core he remains a slave and as such he becomes divided and continually vacillates between these two poles of his personality. "His relationship with Julie creates further fragmentation; because he relates to Julie both as a slave and as a sexual 
aristocrat, he gets torn between his selfish plans and his desire for her." (Reinhert,1971:111) Thus, his 'sympathy' for the upper classes and his love-hate relationship with its representative make him destructive and finally cause his downfall.

The sex war has both individual and class implications. In the 'Preface,' (1969: xvi, xvii) Strindberg suggests that the aristocracy has been weakened due to the battle of the sexes and the women's liberation movement which questioned patriarchal and feudal hierarchies. In their battle for supremacy, the women attacked male constructions of gender and society. The women insidiously destroyed their men and such acts by extension weakened the institutions created, constructed and perpetuated for the preservation of the male self or the dominant class. For instance, Julie's mother through her affairs undermines her husband's authority, sexuality, financial security and his paternity. She ignores his paternal control over his child's upbringing and brings up Julie as a boy. Similarly, the Baroness in The Link brings up her son as a girl to undermine her husband. Julie is trained to be dominant and assertive. Unlike other women of her class, she has not been schooled in the art of enhancing her femininity to at-tract men. She has been taught to hate men while paradoxically being schooled to be like a man. Brought up among farm animals Julie is acutely aware of her biological difference and begins to hate it. Thus, while her mother teaches her to hate her own essential female self, her father teaches her to hate her gender.

Her parents' strife / conflict contribute to the destruction of the family, the estate and the child Julie. Born of an antagonistic union and brought up in a strife-ridden environment, Julie's psyche is infected with a fragmented and ruptured sense of self. Julie further reflects and replicates the selfish, antagonistic principle in her own sexual and social relationships with the opposite sex. The principle of divisiveness and competitiveness gets further transmitted from the sexual to the social plane. The Jean/ Julie relationship represents the conflation of the sexual struggle for supremacy with the class struggle for ascendancy. The degeneration within Julie's family represents the degeneracy of the dissipated and decrepit aristocracy. Her death marks the end of the Count's family and by extension of the aristocracy which she represents. Julie is destroyed by the contrary pulls of her heredity that is her essential weak female self and her environment of sexual strife between her parents for dominance and supremacy. A product of the man-woman conflict, her split self inheres and perpetuates this principle in her own social and sexual relationships. The female represents all that is weak and it is therefore abhorred by both men and women alike.

The machinations of the vampirish women drain the vitality of the aristocracy and gradually lead to its feminization and a corresponding growth in power and vigour of the lower classes. The fall of one leads to the rise of the 'other.' It also suggests a past when the aristocracy was governed by the 'male' principle. The count represents the positive remnant of that glorious past. The aristocracy that Strindberg portrays in Miss Julie is full of 'superannuated trees' (xii) that is decadent, diseased, weak and without a 'Will.' Women according to him are either parasitic, confused, diffused and have no goals, like Julie or they are competitive, vampirish and cannibalistic like her mother. He, therefore, uses Julie to represent a dying aristocracy. In Miss Julie, Strindberg reveals a gendered perspective on class. He chooses to represent the positive aspects of a class through the men and the negative aspects through the women. For instance, Kristin the cook is servile, devout and superstitious. She is not assertive or ambitious and occasionally steals too. There is no redeeming feature in her character and she represents the downside of the lower classes. Jean, on the other hand, is ambitious and assertive and represents the survival spirit of his class. He too steals but it is 
represented as a mark of his cunning intelligence. He is confident of achieving his dream of becoming a Count himself.

The Count and Julie's fiancé present the positive 'male' aspect of the aristocracy. Both these characters never appear on stage but are referred to by the other characters. The Count is represented through his boots, which symbolize authority and power and probably are also the reminder of the lost power and glory of the aristocracy i.e. literally on its last leg. The count is the last male member of his house and as he has no male heir his line will die out with him. He represents the residual remnants of a glorious past. Though Julie's fiancé is not able to satisfy her, he represents positive independence of will in refusing to submit to her domination. The men irrespective of class know what they want. The women on the other hand are confused; they are passionate but ineffective. They are easily fooled by the men because they harbour illusory ideas about love. The upper class woman appears to be more confused and deluded because she has been exposed to new ideas of gender equality. The lower class women like Kristin appear to have a more matter-of-fact and practical approach to sexual matters. Julie needs to believe that she is in 'love' with Jean to accept with equanimity her sexual attraction and intimacy with a lower class man. Significantly, Julie does not command the respect that the Count her father does. The servants discuss Julie and her mother but dare not discuss the Count. Even in his absence, he is a strong presence.

The tragedy of their relationship lies in the fact that both are prisoners of their psyche, class and upbringing. Jean cannot escape his class and Julie her discordant upbringing. Jean can never shed his fears and respect for the Count, can never be free of his slave mentality which makes him quake at the sight of the Count's boots. Julie, too, lacks a definite sense of self. Caught in the hatred of her parents' relationship, she is brought up on contradictory lines. Her mother teaches her to hate men, her father, her own sex, and thus she becomes a half woman and half man continually vacillating between the two. As she herself states: "I haven't got a self; I haven't a thought that I don't get from my father, nor an emotion that I don't get from my mother" (44). This duality and vacillation is reflected in her own relationship with Jean where she starts by taking the male's prerogative in love, but after she is seduced, the woman in her feels the shame and she can no longer sustain her supremacy and falls to the level of imploring Jean to order her to kill herself. Her shame is also the shame of the aristocrat who feels humiliated by the peasants' victory.

As both Jean and Julie are full of contradictions, their relationship too is unstable. In the beginning, Julie appears as the mistress, but with her seduction she falls to Jean's level, and finally escapes out of this situation and gains ascendancy through her suicide. As no relationship is stable, the sexual and the social differences cannot ever be reconciled. The impossibility of reconciliation is also suggested through their self-centered preoccupations, which make them enter into relationships with selfish motives. These selfish drives so isolate them that they cannot understand each other. Jean's confession to Julie proves as much, "I can see you are unhappy . . . but I can't understand you" (32). Thus they can come together only momentarily, to experience a very brief period of happiness, before the violence erupts and destroys everything. Because the man-woman relationship is based on the vampire motif of taking and not on sharing, it becomes steeped in falsities and hatred and remains necessarily transitory in nature.

The traditional image of an ideal relationship between the sexes and the classes is one based on love, trust and sharing. In Miss Julie, 'Hate' seems to be the governing force behind these relations. Julie naively believes that her servants love her till Jean disabuses her of her mistaken beliefs: "No, Miss Julie, they don't love you-they eat your food but behind your 
back they spit at you" (19). Even while Jean warns her against her servants he plans to compromise her by asking her to come into his room. Relationships in Miss Julie are all about power, hierarchy, control and exploitation. Men and women use one another to further their whims and ambitions. Romantic love is highly idealized and overrated. It serves the only practical purpose of bringing the two irreconcilable forces of the male and the female briefly together for a momentary union. In his plays, Strindberg lays bare the ugliness and violence that lies underneath the veneer of love. Love is a false emotion that deludes people. For instance, Julie needs to believe in love to accept and condone her sexual transgression. She uses the idea of love to invest a momentary lustful and impulsive act with meaning and escape the shame. For Jean, the concept is a good tool to seduce women and satisfy his sexual urge and male ego. He is a man of the world, well versed in the manipulative rhetoric of love. He blatantly lies to Julie about his childhood fascination and love for her to win her trust and trap her. It is a game he very consciously and calculatingly plays to rise up the social ladder. He confesses as much to Julie. Jean successfully fabricates his tale to feed into Julie's romantic fantasies. The real and 'dirty' nature of his feelings he reveals only after he has had her and Julie has fallen to his level. Julie is unable to accept her sexuality so crassly. She desperately clings to the illusion of love to make the momentary appear as lasting. Jean too plays along for his own self-preservation and social advancement. He is not able to sustain the illusion for long and begins to feel drained by Julie's parasitic dependence on him. He begins to realize the hollowness of the aristocracy. The weak woman and the dying class conflate in the figure of Julie needing the intervention of Jean the strong male and the resurgent class. Jean lives and Julie dies and yet in the final analysis Julie seems to be the winner. The complex nature of these relationships defies easy categorization. Ultimately there are no winners, the conflict continues with new players.

In such relationships as depicted here, there can be no clear-cut victory: For instance, though Jean seems to have survived because he is the slave and hence stronger, we are made forcefully aware that in giving Julie the razor he has destroyed his own chances of survival. Realizing this, Jean 'turns coward' and refuses to order Julie, to go and kill herself. But as the destruction of each is as inevitable as the conflict, he finally utters the fatal word: "it's terrible-but there's no other way [out] Go ..." (46). There truly is "no other way out.. these basically isolated characters 'cannot combine' but only collide and damage each other". (Williams, 1966: 11)

The Creditors (1898) again presents a bleak picture of human relationships. All relationships are exposed to be based on ambivalent subterfuges and hence to be basically dangerous. The Tekla-Adolph relation reflects one such ambivalent subterfuge. Though they are husband and wife, they address each other as brother and sister. They apparently do this to preserve the purity of the relationship but this rebounds on them and taints the relation with the suggestions of incest. On the other hand, Gustav, Tekla's former husband, uses the disguise of friendship to revenge himself on Tekla by undermining and finally destroying Adolph. Furthermore; Tekla's relationships with her husbands are exposed to be parasitic and vampiric. In this scenario, friends and friendship appear as destructive agents who insidiously infect and destroy a person's sense of identity. Creditors thus presents the negative, souldestroying aspects of each human relationship. As Hartong(2005: 43)rightly comments,

the more we wants things to be different the greater the pain. We seemingly run into contradictions here, because if there is a wish for things to be different, then that is the way it is and that might be welcomed. 
A Dream Play (1902)' in many ways makes explicit the reasons behind the negative drives of human beings. One of the main reasons behind human suffering seems to be the fragmented nature of the universe. This makes each person feel isolated and inadequate because they represent and experience only one aspect of life. Not knowing the totality of human experience makes these characters obsessed with one idea and hence in their relationships with others they cannot understand them, and thus are born relationships full of misunderstandings and strife.

Like other Strindberg characters, Indra's daughter too starts on her experience of human relations with the idealistic notion: Life is hard-but love conquers all." But she soon comes to experience that "love which is the fairest of things is also the bitterest" (Meyer, 1964:206). In fact in this world "nothing is as . . imagined" (197) and thus the "child" which was to be their (the daughter's and the advocate's) "salvation" proves to be their "ruin" (208). The tragedy of human life lies in the fact that one does not have to be guilty to be "contaminated by the petty dirt of life." (219). For instance, the advocate gets contaminated by the crimes of other people.

It is a "curious world of contradictions" (216) and there is no escape from the pain it generates, except through "suffering" which is the only "liberator" (251). The "discord" in the soul created by divided allegiances causes the "small disharmonies" of life which "tear" men and their relationships apart (248). Death represented here through the burning castle and the flowering chrysanthemum, thus, becomes not a symbol of defeat but of a final victory over the discords of life.

"The misery of an imperfect world is most effectively presented in The Ghost Sonata through its masked characters, who in their attempts to forget their own realities convert life into an endless masquerade." (Parker, 1972: 373)This attempt creates a highly complicated web of relationships all of which reflect that what appears to be true is not the real truth. For example, Adele turns out to be not the Colonel's, but Hummel's illegitimate daughter. Thus, in this world of deceptions where nothing reflects the reality, ideals are exposed as masks that try to hide or overlook the reality, of the dirt of life. The tragic reality of this life is that beauty, like the hyacinths in Adele's room, can be poisonous. Thus, mankind's attempts to create harmony and beauty inevitably turn to dust; ideals are thwarted and ugliness prevails.

The tragedy of this human situation is reflected in the Mummy's speech: "We're bound together by our sins and a guilty conscience, I Suppose.... Oh, we've tried dozens of times to split up and to go each his separate way, but, somehow, we're always drawn together again." Furthermore, the self-deceptions of these characters poison the lives of their children and thus infect the very source of life.

The sense of universal contamination and predatoriness is best reflected in Hummel. Himself a cripple, he lives like a vampire, through others, by controlling and appropriating their lives into himself. As he also suggests "the experience of age in his relationship with the student, he reflects the parasitic nature of age which feeds on youthful vitality." (Smedmark, 1966: 41) Furthermore, in his relationship with the vampire cook he is aligned to the lower classes and this reflects the proliferation of the predatory motive from the sphere of personal relationships to the class struggle. As Hummel has also been a vampiric moneylender, his career effectively suggests "the tainting of personal, social, class and business relationships." $(1964: 125)$

The tragedy of these malicious relationships is that : 
it is a tragedy that has got into the bloodstream . . . [into] the living process itself." Thus victims of an imperfect world, ravaged by their own ambivalences, these men and women can do nothing but lament: "Oh, God! why aren't we dead? If only we were dead! (119)

In their anguished death wish is a cry for deliverance that echoes across Strindberg's canon and reflects his nightmare vision.

\section{Conclusion}

Strindberg's plays reflect that all tragic disruptions stem from the conflicting and ambivalent relationships between the sexes. The primary reason behind these disintegrating relationships is the solitary nature of the characters, who most often are divided and maladjusted. To cover up this sense of dislocation, they usually project forth a completely different self from their real one. In its turn this masking of the reality gives rise to relationships that are based on falsities and are hence basically am-bivalent. Thus, while by themselves, they might appear as good and whole, their relationship with the opposite sex makes them aware of their hidden ambivalences and they become monstrous. Seething with repressed feelings of violence and indignation, these relationships only need a pretext to burst forth into the full-fledged battle between the sexes. This battle for supremacy and domination has only one inevitable endthat is the destruction of the weaker partner. But as this battle is also the external manifestation of an inner conflict, the destruction of one necessarily leaves the other maimed and incomplete. "That it is an ongoing process is best illustrated through the cyclical and repetitive pattern of The Road to Damascus." (Williams, 1966: 13) The poisonous effects of this conflict get perpetuated through the children who, to begin with, are innocent victims, but who, in their turn, in their relationships, inevitably poison and contaminate the whole society. It thus, proliferates down from the personal level to contaminate all relations and consequently all social transactions reflect destructive motives. Thus, prisoners of their own selves and the world they create, Strindberg's characters can free themselves only through death, but this study suggests that we should not wait for death to free us from these frustrating conflicts; we can free ourselves through getting close to one another as human beings without being the victims of inferiority and superiority complexes. Humphrey (2008:27) pertinently quotes the Roman dramatist Terence: "I am a man, and I think nothing human alien to me."

\section{References}

Allen, J. Strindberg, August. (1960)The Ghost Sonata, trans. Max Faber in August

Strindberg: Miss Julie and Other Plays. London: Heinmann.

Brustein, R. (1965) " Male and Female in August Strindberg." Modern Drama: Essays in

Criticism. Ed. Travis Bogard and William Oliver. New York: Oxford University Press.

Cooper, H, ed. (1992). August Strindberg, Miss Julie: A Naturalistic Tragedy. London: 
Mthuen,

Harris, A. (1979). August Strindberg, The Father: A Tragedy. Surrey: The Gresham Press.

Harris, A. (1979). Strindberg, The Link: A Tragedy in One Act, trans. Edwin Bjorkman, Eight Best Plays. Surrey: The Gresham Press.

Hartong, L. (2005). From Self to Self: Notes and Quotes in Response to Awakening to the Dream. Salisbury: Non-Duality Press.

Humphrey, N. (2008).Seeing Red: A Study in Consciousness. Massachusetts: Harvard University Press.

Lamm, M. (1952).Modern Drama. Trans. Karin Eliot. Oxford: Basil Blackwell.

Meyer, M . (1964).Strindberg, August: Plays Two. London: Methusen.

Meyer, M.(1987). Strindberg: A Biography. Oxford Lives ser. Oxford: Oxford UP.

Parker, G. The Spectator Seized by the Theater: Strindberg's The Ghost Sonata. Modern Dsrama, XIV (February 1972), 373-386

Reinert, O. (1971). Strindberg: A Collection of Critical Essays, Twentieth Century Views. Englewood Cliffs, N.J: Prentice Hall.

Smedmark, C.R (1966). Essays on Strindberg, Stockholm: Beckmans Bokforlag.

Valency, M. (1963). The Flower and the Castle. New York: Macmillan.

Wheeler, J. (2006). Right Here, Right Now: Seeing Your True Nature as Present Awareness. Salisbury: Non-Duality Press.

Williams, R. (1966). "Strindberg and Modern Tragedy," Essays on Strindberg, ed. Carl Reinhold Smedmark. Stockholm: J. beckmans, Bokforlag. 